\title{
Antioxidant and immunomodulatory activities of Oviductus ranae in mice
}

\author{
Yang Zhang ${ }^{1}$, Yang Liu², Xiudong Yang², Hao Cui², Xiaoxiao Xu², Liping Mao², Hongli Zhou'* \\ ${ }^{1}$ School of Biology and Food Engineering, Changshu Institute of Technology, Changshu, People's Republic of China, ${ }^{2}$ School \\ of Chemistry and Pharmaceutical Engineering, Jilin Institute of Chemical Technology, Jilin, People's Republic of China
}

\begin{abstract}
Oviductus ranae (OR) is a traditional Chinese medicine, which was first recorded in the Compendium of Materia Medica in the Ming Dynasty. OR contains high amounts of proteins and elicits therapeutic effects on neurasthenia, insomnia, and respiratory symptoms, which are related to oxidative stress and immunodeficiency. This study aimed to obtain the potential of OR for the development of functional food possessing antioxidant and immune-enhancement functions in the same dose. In antioxidant evaluation, OR can significantly decrease malondialdehyde and protein carbonyls $(P<0.05, P<0.01)$ and significantly increase total superoxide dismutase and glutathione in a dose-dependent manner $(P<0.05, P<0.01)$ against ethanol-induced oxidative stress in mice at $0.1,1.0$, and $3.0 \mathrm{~g} / \mathrm{kg} \mathrm{BW}$. In immunomodulatory evaluation, OR could significantly enhance the phagocytosis of liver macrophages $(P<0.05, P<0.01)$, delayed-type hypersensitivity response $(P<0.05, P<0.01)$, hemolytic activity $(P<0.05)$, antibody-producing cells $(P<0.05)$, and natural killer cell activity $(P<0.05)$ in the same dose range described in antioxidant evaluation compared with those in the normal control. OR slightly influenced lymphocyte proliferation, peritoneal macrophage phagocytosis, and immune organ indices in mice. Thus, $3.0 \mathrm{~g} / \mathrm{kg} \mathrm{BW}$ OR showed potential for the development of functional food with antioxidant and immune-enhancement activities.
\end{abstract}

Keywords: Oviductus ranae/evaluation/antioxidant activity. Immunomodulatory activity. Functional food.

\section{INTRODUCTION}

Reactive oxygen species (ROS) generated inside cells as metabolism products play a dual role as harmful and beneficial species. Low/moderate ROS concentrations participate in some physiological processes, including signal transduction pathway, mitogenic response induction, cell proliferation, and differentiation in body (Valko et al., 2007). However, when bodies are influenced by harmful environmental stress, such as X-ray irradiation, smoking and alcohol overconsumption, and long-term exposure to heavy metals or organic pollutants, the balance between ROS generation and elimination can be destroyed to produce excess ROS, thereby inducing oxidative stress (Srivastava et al., 2017). ROS-induced oxidative stress can damage DNA, proteins, and lipids (Martinez-Useros et

\footnotetext{
*Correspondence: H. Zhou. School of Chemistry and Pharmaceutical Engineering, Jilin Institute of Chemical Technology, Chengde Street No.45, Longtai District, Jilin, Chin. E-mail: zhouhongli@jlict.edu.cn
}

al., 2017), leading to cellular death and aging (Lee, Wei, 2001), and several diseases, including cancer (Nicolussi et al., 2017), Alzheimer's disease, Parkinson's disease, diabetes (Umeno, Biju, Yoshida, 2017), inflammation (Pillon Barcelos et al., 2017), and chronic obstructive pulmonary disease (Singh et al., 2017).

Endogenous enzyme-based antioxidants and metabolites, such as superoxide dismutase (SOD), glutathione peroxidase, catalases, and glutathione (GSH), can quench excess ROS to reduce the damaging effects of free radicals. Unfortunately, the concentrations of these endogenous antioxidants are usually lower than the level required to scavenge free radicals; thus, exogenous antioxidant supplement may be required in these cases (Szuroczki, Koprivnikar, Baker, 2016). Antioxidants are also involved in their effects on immune enhancement (Knight, 2000). The main components of immune cell membrane are polyunsaturated fatty acids (PUFAs), which are sensitive to free radicals; therefore, antioxidants in immune cells can protect PUFAs against 
oxidative damages, thereby maintaining the integrity and function of membrane lipids, nucleic acids, and cellular proteins (Amir Aslani, Ghobadi, 2016). For example, antioxidant vitamins, such as vitamins $\mathrm{C}$ and $\mathrm{E}$, coupled with carotenoids can increase the number of circulating lymphocytes to increase the rejection response to xenobiotics and evoke the immune system (Bendich, 1996; Szuroczki, Koprivnikar, Baker, 2016).

The Chinese brown frog Rana chensinensis is one of the well-known economic animals farmed in northeast China. Its natural population was listed as the national key-protected wild medicinal material by the Chinese government in 1987 . The economic value of $R$. chensinensis mainly depends on its dried oviduct, Oviductus ranae (OR), which was first recorded in the Compendium of Materia Medica in the Ming Dynasty. According to traditional Chinese medicine, OR can nourish the kidney, strengthen the essence, and moisten the lung to nourish yin. Since 1985, OR has been listed in Chinese Pharmacopeia for the treatment of various ailments, including debilitation, night sweat, neurasthenia, insomnia, and climacteric syndrome (Zhang et al., 2017). Modern pharmacological studies have revealed that OR exerts several activities (Ling et al., 2017; Sui et al., 2016; Zhang et al., 2017), such as antifatigue, reproductive protection, anti-osteoporosis, anti-apoptosis, and estrogenlike effects. Ling et al. (2017) found that OR-containing serum can protect rat ovarian granulosa cells from $\mathrm{H}_{2} \mathrm{O}_{2}$ induced apoptosis by decreasing ROS production and improving the potential of mitochondrial membrane via mitogen-activated protein kinase signaling pathway activation and downregulation of the negative regulators of proliferation. OR is rich in proteins; in some cases, its protein content exceeds 50\% (Huang et al., 2014). Studies associated with proteins from OR (POR) have indicated that POR hydrolysate can enhance immunity by enhancing the phagocytosis of macrophages, by increasing interleukin (IL)-1 $\beta$, IL-6, tumor necrosis factor- $\alpha$, and nitric oxide levels, and by upregulating the mRNA and protein expression of nitric oxide synthase (Huang et al., 2014). Thus far, information regarding the antioxidant and immunomodulatory activities of OR in experimental animals in the same dose is limited.

The genus OR has been mainly explored because it is an essential traditional animal-based medicine with diverse pharmacological effects. The chemical composition, amino acids, and toxicity of OR have been investigated (Zhang et al., 2017). OR also contains $56.87 \% \pm 1.35 \%$ proteins, $4.91 \% \pm 0.17 \%$ fats, $9.39 \% \pm 0.35 \%$ moisture, $5.54 \% \pm$ $0.29 \%$ ash, and 17 amino acids, with threonine having the highest content of $66.35 \mathrm{mg} / \mathrm{g}$ (Table I). In addition, OR is highly safe with a median lethal dose $\left(\mathrm{LD}_{50}\right)$ higher than $20 \mathrm{~g} / \mathrm{kg} \mathrm{BW}$ in mice. Considering the clinical indications of OR related to oxidative stress (Saeidnia, Abdollahi, 2013), we conducted this research to confirm its effects on the status of oxidative stress and to assess its functions on the immune system in the same dose.

TABLE I - Amino acid composition of OR (Zhang et al., 2017)

\begin{tabular}{cc}
\hline Amino acid & $\begin{array}{c}\text { Amino acid composition of } \\
\text { OR (mg/g) }\end{array}$ \\
\hline Aspartic acid & 46.15 \\
${ }^{a}$ Threonine & 66.35 \\
Serine & 30.43 \\
Glutamic acid & 48.37 \\
Glycine & 24.58 \\
Alanine & 15.80 \\
Cystine & 4.49 \\
a'Valine & 23.30 \\
${ }^{a}$ Methionine & 2.96 \\
${ }^{a}$ Isoleucine & 20.81 \\
${ }^{a}$ Leucine & 29.94 \\
Tyrosine & 7.99 \\
${ }^{a}$ Phenylalanine & 18.15 \\
a'Lysine & 30.59 \\
Histidine & 7.18 \\
Arginine & 18.33 \\
Proline & 31.38 \\
'Total & 426.80 \\
'REAA & $45.01 \%$ \\
\hline
\end{tabular}

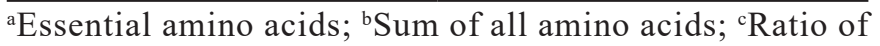
essential amino acids

\section{MATERIAL AND METHODS}

\section{Material}

Freeze-dried OR was provided by Jilin Huangzhihua Pharmaceutical Co., Ltd. (Changchun, Jilin, China) and authenticated by Professor Guang-shu Wang, School of Pharmaceutical Sciences, Jilin University (Changchun, Jilin, China). A voucher specimen (No. HG-2035) was deposited in Jilin Engineering Research Center for Agricultural Resources and Comprehensive Utilization, Jilin Institute of Chemical Technology (Jilin, Jilin, China). Before the experiment was performed, OR was ground into powder and sieved to 100 mesh.

Reagent kits for the determination of malondialdehyde (MDA, thibabituric acid method), total superoxide dismutase (T-SOD, hydroxylamine method), GSH, 
(spectrophotometric method), and PCO (spectrophotometric method) were obtained from Jiancheng Biotechnology Co., Ltd. (Nanjing, Jiangsu, China).

Sheep red blood cell (SRBC) and chicken red blood cell (CRBC) suspensions were procured from Senbeijia Biological Technology Co., Ltd. (Nanjing, Jiangsu, China). Guinea pig serum and calf serum were provided by Jiancheng Biotechnology Co., Ltd. (Nanjing, Jiangsu, China). YAC-1 mouse lymphoma cells were obtained from the Cell Bank of the Chinese Academy of Sciences (Shanghai, China), and Indian ink was obtained from Zeye Biological Technology Co., Ltd. (Shanghai, China). 3-(4,5-Dimethylthiazol-2-yl)-2,5-diphenyl tetrazolium bromide (MTT), lithium lactate, 2-(4-iodophenyl)-3-(4nitrophenyl)-5-phenyltetrazolium chloride, phenazine methosulphate (PMS), nicotinamide adenine dinucleotide (NAD), agarose, concanavalin A (Con A), Drabkin's reagent, and nonidet P-40 (NP-40) were procured from Sigma Aldrich Co., Ltd. (St. Louis, MO, USA). Benzylpenicillin, pentobarbital sodium, and streptomycin were obtained from Civi Chemical Technology Co., Ltd. (Shanghai, China). RPMI 1640 medium, Hanks' solution, and Giemsa stain solution were procured from Thermo Fisher Scientific Inc. (Logan, UT, USA).

Other solvents and reagents were analytical grade and provided by Sigma Aldrich Chemical Co., Ltd. (St. Louis, MO, USA).

\section{Animals}

Male ICR mice (aged 4 weeks, weighing $20.0 \pm 2.0 \mathrm{~g}$ ) with SPF grade (Approval No. SCXK $(\mathrm{Ji})$ 2007-0003) were provided by the Experimental Animal Center of Jilin University (Changchun, Jilin, China). Experimental animals were placed in polypropylene cages and allowed free access to food and water. The feeding conditions were temperature $20 \pm 2{ }^{\circ} \mathrm{C}$, relative humidity $60 \pm 10 \%, 12 \mathrm{~h}$-light/dark cycle, and ventilation frequency of $\geq 10$ times $/ \mathrm{h}$. The animals were accustomed to housing conditions at least 1 week before the experiment. Animal experiments were conducted in compliance with the National Institutes of Health Guide for the Care and Use of Laboratory Animals (NIH Publications No. 8023, revised 1978) and approved by the Animal Care and Welfare Committee of Jilin Institute of Chemical Technology.

\section{Antioxidant evaluation in mice}

In accordance with a previous work (Peng et al., 2015 ) with minor modifications, an ethanol-induced oxidative stress mouse model was used to assess the antioxidant activity of OR. The minimal treatment dose of OR was selected in accordance with the reported literature (Ling et al., 2017), which showed that 0.09 $\mathrm{g} / \mathrm{kg} \mathrm{BW}$ in the rats was taken as the low dose for the evaluation of the use of OR in oxidative stress-induced apoptosis. Thus, $0.1 \mathrm{~g} / \mathrm{kg} \mathrm{BW}$ in mice was chosen as the minimal dose in the present study, and 1.0 (10-fold) and $3.0 \mathrm{~g} / \mathrm{kg} \mathrm{BW}$ (30-fold) were designed as the two other treated doses for the preliminary test (data not shown). Four antioxidant biomarkers, namely, MDA (lipid peroxidation product), T-SOD (antioxidase), GSH (endogenous antioxidant), and PCO (protein oxidation product), were selected.

The mice were randomly divided into five groups (10 mice per group), namely, normal control (NC), model control (MC), and three OR-treated groups. Before the experiment was performed, the OR powder was soaked in distilled water for $12 \mathrm{~h}$ and homogenized using a tissue homogenizer. The mice in the OR-treated groups were administered with OR suspension $(2 \mathrm{~mL} / 100 \mathrm{~g} \mathrm{BW})$ by oral gavage once a day at doses of $0.1,1.0$, and $3.0 \mathrm{~g} / \mathrm{kg}$ $\mathrm{BW}$ for 30 consecutive days. The mice in the $\mathrm{NC}$ group were orally treated with an equal amount of distilled water.

On the last day, after fasting for $12 \mathrm{~h}$, the mice except the NC group were orally administered with $50 \%(\mathrm{v} / \mathrm{v})$ ethanol solution to induce oxidative stress in a dose of 12 $\mathrm{mL} / \mathrm{kg} \mathrm{BW}$. After $6 \mathrm{~h}$, the animals were anesthetized with pentobarbital sodium (50 mg/kg BW, intraperitoneally), and the blood samples were collected from an orbit to prepare the serum to determine T-SOD and MDA through centrifugation at $4000 \mathrm{rpm}$ at $4{ }^{\circ} \mathrm{C}$ for $10 \mathrm{~min}$. The mice were euthanized with carbon dioxide, and the livers were dissected immediately, washed, homogenized in normal saline, and centrifuged at $4000 \mathrm{rpm}$ at $4{ }^{\circ} \mathrm{C}$ for $10 \mathrm{~min}$ to obtain the supernatant for GSH and PCO quantification. MDA, T-SOD, GSH, and PCO were determined in accordance with the methods described in the kits' instructions.

\section{Immunomodulatory evaluation in mice}

The immune-enhancement function of OR in the mice was evaluated in the same dose range $(0.1$, 1.0 , and $3.0 \mathrm{~g} / \mathrm{kg} \mathrm{BW}$ ), and several tests regarding immunomodulatory evaluation were conducted (Fang et al., 2014; Pan et al., 2016; Pan et al., 2013; Xu et al., 2008; Yu et al., 2016).

The mice were randomly divided into five groups (I-V). In each group, the mice were separated into four subgroups (10 mice per subgroup), that is, $\mathrm{NC}$ and three 
different OR-treated subgroups. Group I was used to determine immune organ indices, hemolytic activity, and antibody-producing cells; Group II was utilized to conduct a carbon clearance test; Group III was set for lymphocyte proliferation and NK cell activity; Group IV was assigned for delayed-type hypersensitivity response; and Group V was established for peritoneal macrophages phagocytosing CRBC. The mice in the OR-treated groups were orally administered at $0.1,1.0$, and $3.0 \mathrm{~g} / \mathrm{kg} \mathrm{BW}$ once daily for 30 consecutive days, and the mice in the NC groups were treated with an equal amount of distilled water.

\section{Hemolytic activity, antibody-producing cells, and immune organ indices}

On the 25th day, the mice in Group I were immunized by intraperitoneally injecting $0.2 \mathrm{~mL}$ of SRBC $(10 \%, \mathrm{v} / \mathrm{v})$ once a day. On the 30th day, the mice were weighed and anesthetized with pentobarbital sodium $(50 \mathrm{mg} / \mathrm{kg} \mathrm{BW}$, intraperitoneally). Their blood samples were collected from the orbit, stored at $4{ }^{\circ} \mathrm{C}$ for $1 \mathrm{~h}$, and centrifuged at $4000 \mathrm{rpm}$ for $10 \mathrm{~min}$. The resulting supernatant was diluted 400-fold with normal saline, and $1 \mathrm{~mL}$ of the diluted serum was mixed with $0.5 \mathrm{~mL}$ of SRBC $(10 \%, \mathrm{v} / \mathrm{v})$ and $1.0 \mathrm{~mL}$ of guinea pig serum $(8 \%, \mathrm{v} / \mathrm{v})$ at $37^{\circ} \mathrm{C}$ for $30 \mathrm{~min}$. The mixtures were centrifuged at $2000 \mathrm{rpm}$ for $10 \mathrm{~min}$, and 1.0 $\mathrm{mL}$ of supernatant was mixed with $3.0 \mathrm{~mL}$ of Drabkin's reagent. Similarly, $0.25 \mathrm{~mL}$ of SRBC and $3.75 \mathrm{~mL}$ of Drabkin's solution were mixed for $10 \mathrm{~min}$ as a positive control. The optical density (OD) at $540 \mathrm{~nm}$ was measured, and the half value of hemolysis $\left(\mathrm{HC}_{50}\right)$ was calculated as follows: $\mathrm{HC}_{50}=\left(\mathrm{OD}_{\text {sample }} / \mathrm{OD}_{\text {positive control }}\right) \times 400$.

After blood extraction, the mice were euthanized with carbon dioxide, and the spleen and thymus were excised and weighed immediately. The immune organ indices were expressed as follows: thymus or spleen index $(\mathrm{mg} / \mathrm{g})=$ thymus or spleen weight $(\mathrm{mg}) /$ body weight $(\mathrm{g})$. The collected spleens were pooled in Hank's solution and homogenized to prepare cell suspensions, which were subsequently resuspended in $5 \mathrm{~mL}$ of RPMI-1640 medium and adjusted to a concentration of $5 \times 10^{6}$ cells/ $\mathrm{mL}$. The medium containing agarose $(1 \%, \mathrm{w} / \mathrm{v})$ was kept at $45-50{ }^{\circ} \mathrm{C}$, mixed with an equal amount of Hank's solution ( $\mathrm{pH} 7.2-7.4)$, and split into test tubes $(0.5 \mathrm{~mL}$ per tube). Afterward, $20 \mu \mathrm{L}$ of splenocyte suspensions and $50 \mu \mathrm{L}$ of SRBC were added to the test tubes, mixed, and poured onto a glass slide containing an agarose layer. After the blood clotted, the glass slide was incubated at 37 ${ }^{\circ} \mathrm{C}$ for $1.5 \mathrm{~h}$, guinea pig serum $(8 \%, \mathrm{v} / \mathrm{v})$ was poured into the frame of glass slide, and continuously incubated at 37 ${ }^{\circ} \mathrm{C}$ for another $1.5 \mathrm{~h}$. The number of plaque-forming cells (PFC) was counted.

\section{Carbon clearance test}

On the last day, the mice in Group II were weighed and treated with $0.5 \mathrm{~mL}$ of diluted Indian ink (1: 4 diluted with normal saline) through tail intravenous injection. Afterward, $20 \mu \mathrm{L}$ of blood samples was collected from the angular vein plexus at $2 \mathrm{~min}\left(\mathrm{t}_{1}\right)$ and $10 \mathrm{~min}\left(\mathrm{t}_{2}\right)$. The blood samples were mixed with $2.0 \mathrm{~mL}$ of sodium carbonate solution $(0.1 \%, \mathrm{w} / \mathrm{v})$, and the OD values $\left(\mathrm{OD}_{1}\right.$ for $2 \mathrm{~min}$ and $\mathrm{OD}_{2}$ for $10 \mathrm{~min}$ ) were measured at $600 \mathrm{~nm}$. The mice were euthanized with carbon dioxide, and the livers and spleens were immediately harvested and weighed. The phagocytic index $(\alpha)$ and the carbon clearance index $(\mathrm{k})$ were calculated on the basis of the following formula:

$$
\mathrm{k}=\left(\operatorname{lgOD} \mathrm{D}_{1}-\operatorname{lgOD} \mathrm{D}_{2}\right) /\left(\mathrm{t}_{2}-\mathrm{t}_{1}\right) \text {, and } \alpha=[\mathrm{A} \times(\mathrm{k}) 1 / 3] /(\mathrm{B}+\mathrm{C}) \text {, }
$$

where $\mathrm{A}$ is the body weight, $\mathrm{B}$ is the liver weight, and $\mathrm{C}$ is the spleen weight.

\section{Lymphocyte proliferation and NK cell activity assays}

On the 30th day, the mice in Group III were euthanized with carbon dioxide. The spleens were immediately removed and homogenized in Hank's solution to prepare single-cell suspensions, which were resuspended in RPMI 1640 complete medium (RPMI 1640 medium containing $10 \%$ calf serum, $100 \mathrm{U} / \mathrm{mL}$ benzylpenicillin, and $100 \mathrm{U} / \mathrm{mL}$ streptomycin) and adjusted to a concentration of $3 \times 10^{6}$ cells $/ \mathrm{mL}$. In $24-$ well plates, splenocyte suspensions from each mouse were equally divided into two wells ( $1 \mathrm{~mL}$ per well) and cultured with $7.5 \mu \mathrm{g} / \mathrm{mL}$ of ConA as a stimulated sample or without ConA as a nonstimulated sample. The sample was incubated in an atmosphere with $5 \% \mathrm{CO}_{2}$ at $37{ }^{\circ} \mathrm{C}$ for $68 \mathrm{~h}, 0.7 \mathrm{~mL}$ of supernatant was removed from each well. Afterward, $0.7 \mathrm{~mL}$ of RPMI-1640 medium without calf serum and $50 \mu \mathrm{L}$ of MTT $(5 \mathrm{mg} / \mathrm{mL})$ were added to each well for another $4 \mathrm{~h}$ of incubation. Finally, $1 \mathrm{~mL}$ of acidic isopropanol was transferred into each well and mixed to dissolve the purple formazan crystals. The OD values at $570 \mathrm{~nm}$ were measured, and the lymphocyte proliferation of OR was evaluated on the basis of the following formula:

$$
\mathrm{OD}_{\text {difference }}=\mathrm{OD}_{\text {stimulated sample }}-\mathrm{OD}_{\text {nonstimulated sample }}
$$

Splenocytes (effector cells) were prepared in accordance with the above mentioned method to evaluate the splenic NK cell activity, and lactate dehydrogenase (LDH)-releasing method was applied to examine the NK cell activity by using YAC-1 cells as target cells. Before the experiment was performed, the YAC-1 cell suspensions were adjusted to a concentration of $4 \times 10^{5}$ cells $/ \mathrm{mL}$, and 
the splenocytes were adjusted to a concentration of $2 \times 10^{7}$ cells $/ \mathrm{mL}$. Subsequently, $100 \mu \mathrm{L}$ of splenocyte suspensions and $100 \mu \mathrm{L}$ of YAC- 1 cell suspensions were added to one well of a 96-well plate as the experimental LDH release of the effector/target cell coculture group (tested group). Then, $100 \mu \mathrm{L}$ of YAC- 1 cell suspensions and $100 \mu \mathrm{L}$ of RPMI-1640 medium were mixed as the spontaneous LDH release control group of the target cells (negative control). Afterward, $100 \mu \mathrm{L}$ of YAC- 1 cell suspensions and $100 \mu \mathrm{L}$ of NP40 $(1 \%, \mathrm{w} / \mathrm{v})$ were mixed as the total LDH release control group of the target cells (positive control). The plates were incubated in an atmosphere with $5 \% \mathrm{CO}_{2}$ at $37^{\circ} \mathrm{C}$ for $4 \mathrm{~h}$ and centrifuged at $1500 \mathrm{rpm}$ for $5 \mathrm{~min}$, and $100 \mu \mathrm{L}$ of supernatant in each well was collected in another 96-well plate for the activity test. Then, 100 $\mu \mathrm{L}$ of $\mathrm{LDH}$ substrate solution $\left(5 \times 10^{-2} \mathrm{~mol} / \mathrm{L}\right.$ lithium lactate, $6.6 \times 10^{-4} \mathrm{~mol} / \mathrm{L} \mathrm{INT}, 2.8 \times 10^{-4} \mathrm{~mol} / \mathrm{L} \mathrm{PMS}$, and $1.3 \times 10^{-3} \mathrm{~mol} / \mathrm{L}$ NAD) was added to each well and mixed at room temperature for $10 \mathrm{~min}$. The reaction was quenched by adding $30 \mu \mathrm{L}$ of $1 \mathrm{~mol} / \mathrm{L}$ hydrochloric acid. The OD value at $490 \mathrm{~nm}$ was determined, and the NK cell activity was calculated by the following equation: NK cell activity $(\%)=\left(\mathrm{OD}_{\text {tested group }}-\mathrm{OD}_{\text {negative control }}\right) /\left(\mathrm{OD}_{\text {positive control }}\right.$ $\left.-\mathrm{OD}_{\text {negative control }}\right) \times 100$.

\section{Delayed-type hypersensitivity response}

On the 25th day, the mice in Group IV were immunized with $0.2 \mathrm{~mL}$ of $\operatorname{SRBC}(2 \%, \mathrm{v} / \mathrm{v})$ through intraperitoneal injection once daily. After 4 days (day 29), the thickness of each mouse's left hind voix pedis was measured, and $20 \mu \mathrm{L}$ of SRBC $(20 \%, \mathrm{v} / \mathrm{v})$ was injected into the left hind voix pedis of each mouse. After $24 \mathrm{~h}$ (day 30), the thickness of the left hind voix pedis was measured again. The swelling of voix pedis was expressed as the difference in the thickness of each mouse's left hind voix pedis between days 29 and 30 .

\section{Peritoneal macrophages phagocytosing CRBC}

On the 30th day, the mice in Group V were injected with $1 \mathrm{~mL}$ of CRBC $(20 \%, \mathrm{v} / \mathrm{v})$ via the abdominal cavity. After $30 \mathrm{~min}$, the mice were euthanized with carbon dioxide, injected with $2 \mathrm{~mL}$ of Hanks' solution via the abdominal cavity, and massaged on the abdomen twenty times to fully leach out the peritoneal macrophage. The abdominal cavities of the mice were cut open with a small incision, and $1 \mathrm{~mL}$ of peritoneal fluid was transferred onto glass slides. The glass slides were incubated at 37 ${ }^{\circ} \mathrm{C}$ for $20 \mathrm{~min}$, rinsed with normal saline, dried, fixed with methanol, and stained with Giemsa stain $(4 \%, \mathrm{v} / \mathrm{v})$. Under a microscope, 100 macrophages per mouse were examined to count the macrophages phagocytosing
CRBC. The phagocytic rate was calculated using the following formula: the phagocytic rate $(\%)=$ the number of macrophage phagocytosing $\mathrm{CRBC} /$ the number of counting macrophages $\times 100$, and the phagocytosis index $=$ the total number of phagocytosed $\mathrm{CRBC} /$ the number of counting macrophages.

\section{Statistical analysis}

Data were represented as mean \pm or $+\mathrm{SD}$ (standard deviation). One-way ANOVA was conducted using SPSS19.0 (SPSS Inc., Chicago, USA). When variance was homogeneous, the least significance difference was applied to estimate the differences between groups. When variance was heterogeneous, Tamhane's test was adopted. $P<0.05$ was considered significant.

\section{RESULTS AND DISCUSSION}

\section{Antioxidant evaluation in mice}

Levels or activities of some endogenous substances and enzymes can directly reflect the real status of oxidative stress in the body. Excess free radicals in vivo easily react with PUFAs to produce lipid peroxides, and MDA is the most common product of lipid peroxidation, which is in proportion to the degree of oxidative damage (Esterbauer, Schaur, Zollner, 1991). By contrast, PCO, an irreversible form of protein modification, has been reported to be more stable than MDA. Under the condition of oxidative stress, PCO is usually formed earlier than other oxidative damage-related biomarkers (Weber, Davies, Grune, 2015). Superoxide dismutases (SODs) are an antioxidase that scavenge superoxides by converting a highly reactive superoxide radical to a relatively lower hydrogen peroxide through dismutation. The body has three SOD isozymes (SOD-1, SOD-2, and SOD-3), which catalyze the same reaction but exhibit different enzymatic properties and localizations ( $\mathrm{Hu}, \mathrm{Klann}$, and Thiels, 2007). GSH is a cysteine-based endogenous antioxidant, which widely participates in the detoxification of xenobiotic substances, coupled with free radical antioxidation, because of the existence of a thiol group (Bray, Taylor, 1993). The effects of OR on several oxidative stress-related biomarkers in the present investigation are shown in Figure 1. Significant differences $(P<0.01)$ in MDA, T-SOD, GSH, and PCO were found in $\mathrm{MC}$ compared with those in $\mathrm{NC}$, suggesting that an ethanol-induced oxidative stress mouse model is well established.Significant differences $(P<0.05, P<$ $0.01)$ in MDA and GSH in all of the OR-treated groups were noted compared with those in $\mathrm{MC}$, and significant 
differences $(P<0.05, P<0.01)$ in T-SOD and PCO were found at 1.0 and $3.0 \mathrm{~g} / \mathrm{kg} \mathrm{BW}$ of the OR-treated groups. The effects increased as the dose increased, especially T-SOD, GSH, and PCO, and dose-dependent manners $(P<0.05, P<0.01)$ were oberved in those cases. These results indicated that OR elicited an antioxidant activity against oxidative stress induced by ethanol in the mice by decreasing MDA and PCO and by increasing T-SOD and GSH. The $3.0 \mathrm{~g} / \mathrm{kg} \mathrm{BW}$ in the mice was a highly potential dose candidate for the development of OR as an antioxidant functional food.

The in vivo antioxidant activity of OR may be contributed by the absorbed digestive products of protein because the protein content in OR is $56.87 \% \pm 1.35 \%$. The main digestive products of proteins are amino acids and peptides; their amino acid types and compositions

A
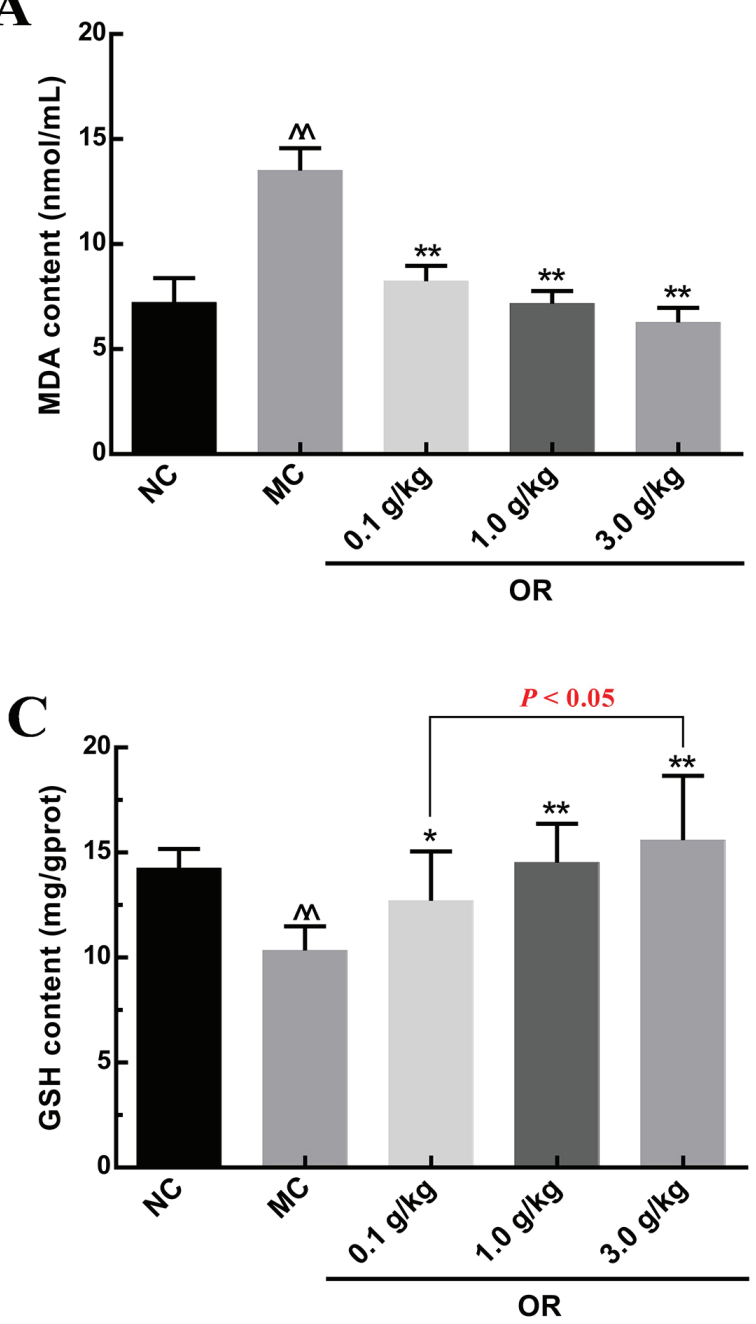

are closely related to antioxidant activities (Wang et al., 2014). Previous studies manifested that some amino acids, including threonine, cysteine, methionine, tryptophan, tyrosine, histidine, phenylalanine, glutamic acid, aspartic acid, and lysine, can act as antioxidants (Habte-Tsion et al., 2016; Oh et al., 2016; Saiga, Tanabe, Nishimura, 2003). Table I shows that eight antioxidant amino acids are present in OR: aspartic acid $(46.15 \mathrm{mg} / \mathrm{g})$, threonine $(66.35 \mathrm{mg} / \mathrm{g})$, glutamic acid $(48.37 \mathrm{mg} / \mathrm{g})$, methionine $(2.96 \mathrm{mg} / \mathrm{g})$, tyrosine $(7.99 \mathrm{mg} / \mathrm{g})$, phenylalanine $(18.15$ $\mathrm{mg} / \mathrm{g})$, lysine $(30.59 \mathrm{mg} / \mathrm{g})$, and histidine $(7.18 \mathrm{mg} / \mathrm{g})$, which account for $51.68 \%$ of the total amount of amino acids in OR. The essential amino acids in OR (Table I) may also exert their beneficial effects against oxidative stress (D'Antona et al., 2016; Eisler, Fröhlich, and Heidenreich, 2004).
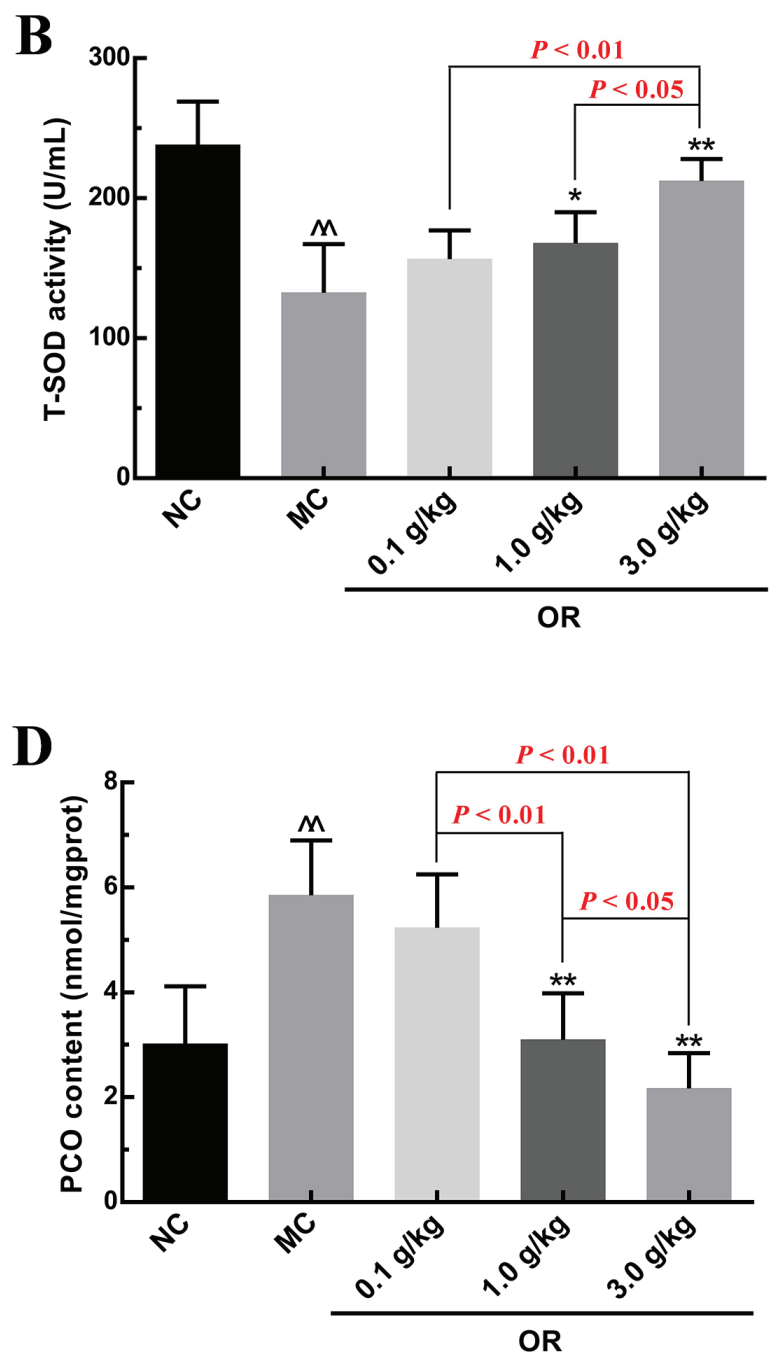

FIGURE 1 - Effects of OR on (A) MDA, (B) T-SOD, (C) GSH, and (D) PCO. Data denoted are means + SD ( $n=10)$. Different symbols indicated statistically significant differences. ${ }^{\wedge} P<0.01$ compared with the $\mathrm{NC}$ group; ${ }^{*} P<0.05$ compared with $\mathrm{MC}$ group; ${ }^{* *} P<0.01$ compared with the PC group. MDA, malonaldehyde; T-SOD, total superoxide dismutase; GSH, glutathione; PCO, protein carbonyls; OR, Oviductus ranae; $\mathrm{NC}$, normal control; $\mathrm{MC}$, model control. 


\section{Immunomodulatory evaluation in mice}

ROS-based free radicals are important in innate and adaptive immune responses (Knight, 2000). They may influence adaptive immunity through the regulation of $\mathrm{T}$ cell activation, and the exposure of T-lymphocytes to normal physiological concentrations of ROS not only circumvents the requirement for signaling initiation but also enlarges signaling cascades induced by weak receptor stimulation (Hehner et al., 2000). However, when an imbalance between prooxidant and antioxidant systems occurs, the activated T cells can be killed by excess ROS (Hildeman et al., 2003; Devadas et al., 2002), suggesting that the inhibition of oxidative stress can increase the quantity of activated $T$ cells, subsequently enhancing immunity. Thus, in this work, followed by antioxidant evaluation, the immunomodulatory activities of OR were assessed in the same dose range.

Effects of OR on immune organ indices, lymphocyte proliferation, delayed-type hypersensitivity response, hemolytic activity, and antibody-producing cells

Adaptive immune responses in the body include defenses against infection or immunization, which consist of cellular and humoral immunities. The antibody response evoked by immunization with a foreign antigen is an important assay of immune function (LeMaoult, Szabo, and Weksler, 1997). After the mice were immunized with SRBC, B-lymphocytes secreted hemolysin, and the content of hemolysin in the serum could be used to estimate the status of humoral immune function. In addition to releasing various cytokines, T-lymphocytes could also directly eliminate the target cells. Thus, the proliferation of T-lymphocytes is essential for the activation cascade of cellular and humoral immune responses (Yu et al., 2016). Table II shows that the OR treatment increased the half value of hemolysis $\left(\mathrm{HC}_{50}\right.$, hemolytic activity), the number of PFC (antibody-producing cells), lymphocyte proliferation, and swelling degree of voix pedis (delayed-type hypersensitivity response) in the mice as the dose increased. Significant differences $(P<0.05)$ in $\mathrm{HC}_{50}$ and PFC were found in $3.0 \mathrm{~g} /$ $\mathrm{kg} \mathrm{BW}$ of the OR-treated group, and significant differences $(P<0.05, P<0.01)$ in the swelling degree of voix pedis were observed in 1.0 and $3.0 \mathrm{~g} / \mathrm{kg} \mathrm{BW}$ of the OR-treated groups compared with those in NC. However, no significant differences in lymphocyte proliferation were noted. For immune organ weights, OR slightly affected the thymus and spleen indices compared with those of NC. This observation is consistent with the results of previous work (Zhang et al., 2017), which demonstrated that OR treatment has no effects on the relative organ weights of rats in a repeated dose in a 28-day toxicity study.

These results indicated that OR might enhance cellular and humoral immunities by increasing the hemolytic activity, antibody-producing cells, and delayedtype hypersensitivity response in the mice. For lymphocyte proliferation, an increase in dose should be further investigated to confirm the effects of OR on lymphocyte proliferation.

\section{Effects of OR on mononuclear phagocytic function}

The capacity of the body to fight against infection is attributed not only to adaptive immune responses to specific antigens mediated by $\mathrm{T}$ and $\mathrm{B}$ lymphocytes but also to innate immune responses (Xu et al., 2008). The mononuclear phagocyte system (MPS) is a family of cells consisting of bone marrow progenitors, blood monocytes, and tissue macrophages. Among them, monocytes and macrophages originate from bone marrow progenitors, and macrophages are differentiated from monocytes. The main immune function of monocytes and macrophages resides in their phagocytosis of pathogenic organisms

TABLE II - Effects of OR on hemolytic activity, antibody-producing cells, lymphocyte proliferation, delayed-type hypersensitivity response, and immune organ indices in mice

\begin{tabular}{|c|c|c|c|c|c|c|}
\hline \multirow{2}{*}{ Group } & \multirow[b]{2}{*}{$\mathrm{HC}_{50}$} & \multirow{2}{*}{$\begin{array}{c}\text { PFC } \\
\left(10^{3} / \text { spleen }\right)\end{array}$} & \multirow{2}{*}{$\begin{array}{c}\text { Lymphocyte } \\
\text { proliferation } \\
\left(\text { OD }_{\text {difference }}\right)\end{array}$} & \multirow{2}{*}{$\begin{array}{c}\text { Degree of voix } \\
\text { pedis swelling } \\
(\mathrm{mm})\end{array}$} & \multicolumn{2}{|c|}{ Immune organ indexes } \\
\hline & & & & & Thymus (mg/g) & Spleen (mg/g) \\
\hline $\mathrm{NC}$ & $163.5 \pm 9.6$ & $180.2 \pm 9.4$ & $0.155 \pm 0.010$ & $0.52 \pm 0.06$ & $2.95 \pm 0.08$ & $4.85 \pm 0.13$ \\
\hline $0.1 \mathrm{~g} / \mathrm{kg}$ & $169.2 \pm 6.3$ & $183.6 \pm 6.8$ & $0.160 \pm 0.009$ & $0.54 \pm 0.08$ & $2.93 \pm 0.05$ & $4.83 \pm 0.19$ \\
\hline $1.0 \mathrm{~g} / \mathrm{kg}$ & $174.1 \pm 8.2$ & $186.4 \pm 11.6$ & $0.161 \pm 0.014$ & $0.58 \pm 0.04^{*}$ & $2.96 \pm 0.05$ & $4.87 \pm 0.16$ \\
\hline $3.0 \mathrm{~g} / \mathrm{kg}$ & $186.7 \pm 12.5^{*}$ & $190.6 \pm 15.2^{*}$ & $0.163 \pm 0.011$ & $0.61 \pm 0.05^{* *}$ & $2.98 \pm 0.06$ & $4.86 \pm 0.18$ \\
\hline
\end{tabular}

Data denoted were means \pm SD $(n=10)$. Different symbols indicate statistically significant differences, ${ }^{*} P<0.05$ and ${ }^{* *} P<0.01$ compared with $\mathrm{NC}$ group. $\mathrm{HC}_{50}$, the half value of hemolysis; $\mathrm{PFC}$, the number of plague forming cells; $\mathrm{OD}$, the value of optical density; OR, Oviductus ranae; NC, normal control. 
TABLE III - Effects of OR on the carbon clearance function of mononuclear macrophages and peritoneal macrophages phagocytosing $\mathrm{CRBC}$ in mice

\begin{tabular}{cccc}
\hline Group & $\begin{array}{c}\text { Phagocytic index of carbon } \\
\text { clearance }\end{array}$ & Phagocytic rate of CRBC (\%) & Phagocytic index of CRBC \\
\hline $\mathrm{NC}$ & $6.50 \pm 0.42$ & $35.6 \pm 4.23$ & $0.43 \pm 0.04$ \\
$0.1 \mathrm{~g} / \mathrm{kg}$ & $6.64 \pm 0.34$ & $37.3 \pm 5.11$ & $0.44 \pm 0.05$ \\
$1.0 \mathrm{~g} / \mathrm{kg}$ & $6.91 \pm 0.56^{*}$ & $35.4 \pm 6.24$ & $0.42 \pm 0.06$ \\
$3.0 \mathrm{~g} / \mathrm{kg}$ & $7.15 \pm 0.53^{* *}$ & $36.5 \pm 4.52$ & $0.45 \pm 0.03$ \\
\hline
\end{tabular}

Data denoted were means \pm SD $(n=10)$. Different symbols indicate statistically significant differences, ${ }^{*} P<0.05$ and ${ }^{* *} P<0.01$ compared with NC group. CRBC, the chicken red blood cells; OR, Oviductus ranae; NC, normal control.

(Chen et al., 2010; Hume, 2006). Table III shows that OR in doses of 1.0 and $3.0 \mathrm{~g} / \mathrm{kg} \mathrm{BW}$ significantly enhanced the phagocytic capacities of mononuclear macrophages in carbon clearance compared with those in NC $(P<0.05, P$ $<0.01)$. By contrast, OR slightly affected the phagocytosis of peritoneal macrophages phagocytosing CRBC, and no statistically significant differences were observed compared with those in NC.

These results indicated that OR might chiefly enhance the phagocytosis of liver macrophages instead of peritoneal macrophages and elicit more effects on Kupffer cells than on other macrophages because ink is mainly cleared by liver macrophages, which mainly consist of Kupffer cells (Xu et al., 2008).

\section{Effects of OR on NK cell activity}

In addition to MPS, NK cells, a kind of granular lymphocytes derived from bone marrow, act as major components of innate immunity. They mainly reside in spleen and spontaneously possess capabilities to kill pathogen-infected and tumor cells (Yu et al., 2016). Figure 2 shows that OR treatment enhanced the NK cell activity as the dose increased, and significant differences $(P<0.05)$ were observed between NC and $3.0 \mathrm{~g} / \mathrm{kg} \mathrm{BW}$ of the OR-treated groups.

In the same dose range $(0.1,1.0$, and $3.0 \mathrm{~g} / \mathrm{kg} \mathrm{BW})$ of antioxidant evaluation, OR can enhance delayed-type hypersensitivity response, hemolytic activity, antibodyproducing cells, liver macrophage phagocytosis, and NK cell activity, but OR slightly affected lymphocyte proliferation, peritoneal macrophage phagocytosis, and immune organ indices. In mice, $3.0 \mathrm{~g} / \mathrm{kg} \mathrm{BW}$ is also a dose candidate for the development of OR as an immuneenhancement functional food. The immunomodulatory capacities of OR can also be attributed to its absorbed amino acids. Amino acids play an important in immune responses by regulating the activation of lymphocytes, NK cells, and macrophages; the production of cytokines

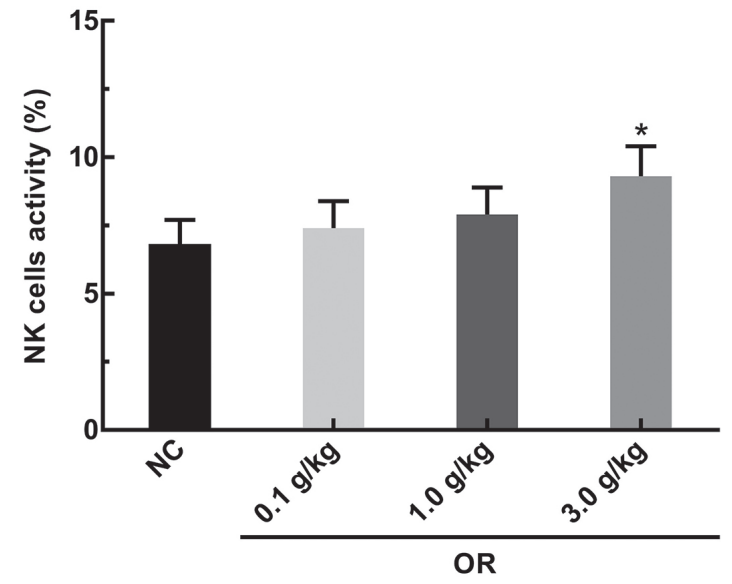

FIGURE 2 - Effects of OR on NK cell activity. Data are means $\pm \mathrm{SD}(\mathrm{n}=10)$. The symbol $(*)$ indicates significant differences. ${ }^{*} P<0.05$ compared with the NC group. NK cells, natural killer cells; OR, Oviductus ranae; NC, normal control.

and antibodies; and the state of cellular redox, lymphocyte proliferation, and gene expression (Li et al., 2007).

\section{CONCLUSION}

In conclusion, OR exerts antioxidant and immunomodulatory activities in mice in the same dose range. It can decrease MDA and PCO, increase T-SOD and GSH, and enhance liver macrophage phagocytosis, delayed-type hypersensitivity response, hemolytic activity, antibodyproducing cells, and NK cell activity. Conversely, OR slightly affects lymphocyte proliferation, peritoneal macrophage phagocytosis, and immune organ indices. Our results suggest that $3.0 \mathrm{~g} / \mathrm{kg} \mathrm{BW}$ is a promising dose candidate for the development of OR as a functional food with antioxidant and immune-enhancement functions.

\section{CONFLICTS OF INTEREST}

The authors declare no conflict of interest. 


\section{ACKNOWLEDGMENTS}

This study was financed by the Program of Jilin Provincial Science and Technology Department (Grant No. 20150311044YY), the Scientific Foundation of Jilin Institute of Chemical Technology (Grant No. 2016032, 2017013), and the Program of Jilin Municipal Bureau of Science and Technology (Grant No. 201750254).

\section{REFERENCES}

Amir Aslani B, Ghobadi S. Studies on oxidants and antioxidants with a brief glance at their relevance to the immune system. Life Sci. 2016;146:163-73.

Bendich A. Antioxidant vitamins and human immune responses. Vitam Horm. 1996;52(1):35-62.

Bray TM, Taylor CG. Tissue glutathione, nutrition, and oxidative stress. Can J Physiol Pharmacol. 1993;71(9):746-51.

Chen JR, Yang ZQ, Hu TJ, Yan ZT, Niu TX, Wang L, et al. Immunomodulatory activity in vitro and in vivo of polysaccharide from Potentilla anserine. Fitoterapia. 2010;81(8):1117-24.

D’Antona G, Tedesco L, Ruocco C, Corsetti G, Ragni M, Fossati A, et al. A peculiar formula of essential amino acids prevents rosuvastatin myopathy in mice. Antioxid Redox Signal. 2016;25(11):595-608.

Devadas S, Zaritskaya L, Rhee SG, Oberley L, Williams MS. Discrete generation of superoxide and hydrogen peroxide by $\mathrm{T}$ cell receptor stimulation: selective regulation of mitogenactivated protein kinase activation and fas ligand expression. J Exp Med. 2002;195(1):59-70.

Eisler H, Fröhlich KU, Heidenreich E. Starvation for an essential amino acid induces apoptosis and oxidative stress in yeast. Exp Cell Res. 2004;300(2): 345-53.

Esterbauer H, Schaur RJ, Zollner H. Chemistry and biochemistry of 4-hydroxynonenal, malonaldehyde and related aldehydes. Free Radic Biol Med. 1991;11(1):81-128.

Fang J, Liang CL, Jia XD, Li N. Immunotoxicity of acrylamide in female BALB/c mice. Biomed Environ Sci. 2014;27(6):401-9.
Habte-Tsion HM, Ren M, Liu B, Ge X, Xie J, Chen R. Threonine modulates immune response, antioxidant status and gene expressions of antioxidant enzymes and antioxidant-immunecytokine-related signaling molecules in juvenile blunt snout bream (Megalobrama amblycephala). Fish Shellfish Immun. 2016;51:189-199.

Hehner SP, Breitkreutz R, Shubinsky G, Unsoeld H, SchulzeOsthoff K, Schmitz ML, et al. Enhancement of T cell receptor signaling by a mild oxidative shift in the intracellular thiol pool. J Immunol. 2000;165(8):4319-28.

Hildeman DA, Mitchell T, Kappler J, Marrack P. T cell apoptosis and reactive oxygen species. J Clin Invest. 2003;111(5):575-81.

Hu D, Klann E, Thiels E. Superoxide dismutase and hippocampal function: age and isozyme matter. Antioxid Redox Signal. 2007;9(2):201-10.

Huang D, Yang L, Wang C, Ma S, Cui L, Huang S, et al. Immunostimulatory activity of protein hydrolysate from Oviductus ranae on macrophage in vitro. Evid Based Complement Alternat Med. 2014;2014:180234.

Hume DA. The mononuclear phagocyte system. Curr Opin Immunol. 2006;18(1):49-53.

Knight JA. Review: free radicals, antioxidants, and the immune system. Ann Clin Lab Sci. 2000;30(2):145-58.

Lee HC, Wei YH. Mitochondrial alterations, cellular response to oxidative stress and defective degradation of proteins in aging. Biogerontology. 2001;2(4):231-44.

LeMaoult J, Szabo P, Weksler ME. Effect of age on humoral immunity, selection of the B-cell repertoire and B-cell development. Immunol Rev. 1997;160:115-26.

Li P, Yin YL, Li D, Kim SW, Wu G. Amino acids and immune function. Br J Nutr. 2007;98(2):237-52.

Ling XM, Zhang XH, Tan Y, Yang JJ, Ji B, Wu XR, et al. Protective effects of Oviductus Ranae-containing serum on oxidative stress-induced apoptosis in rat ovarian granulosa cells. J Ethnopharmacol. 2017; 208:138-148.

Martinez-Useros J, Li W, Cabeza-Morales M, Garcia-Foncillas J. Oxidative stress: A new target for pancreatic cancer prognosis and treatment. J Clin Med. 2017;6(3):29. 
Nicolussi A, D’Inzeo S, Capalbo C, Giannini G, Coppa A. The role of peroxiredoxins in cancer. Mol Clin Oncol. 2017;6(2):139-153.

Oh M, Kim EK, Jeon BT, Tang Y, Kim MS, Seong HJ, et al. Chemical compositions, free amino acid contents and antioxidant activities of Hanwoo (Bos taurus coreanae) beef by cut. Meat Sci. 2016;119:16-21.

Pan DD, Wu Z, Liu J, Cao XY, Zeng XQ. Immunomodulatory and hypoallergenic properties of milk protein hydrolysates in ICR mice. J Dairy Sci. 2013;96(8):4958-64.

Pan Y, Lei Z, Wei X, Hao W. TAK1 deficiency in dendritic cells inhibits adaptive immunity in SRBC-immunized C57BL/6 mice. FEBS Open Bio. 2016;6(6):548-57.

Peng KZ, Yang X, Zhou HL, Pan SX. Safety evaluation, in vitro and in vivo antioxidant activity of the flavonoid-rich extract from Maydis stigma. Molecules. 2015;20(12):22102-12.

Pillon Barcelos R, Freire Royes LF, Gonzalez-Gallego J, Bresciani G. Oxidative stress and inflammation: liver responses and adaptations to acute and regular exercise. Free Radic Res. 2017;51(2):222-236.

Saeidnia S, Abdollahi M. Toxicological and pharmacological concerns on oxidative stress and related diseases. Toxicol Appl Pharmacol. 2013;273(3):442-55.

Saiga A, Tanabe S, Nishimura T. Antioxidant activity of peptides obtained from porcine myofibrillar proteins by protease treatment. J Agric Food Chem. 2003;51(12):3661-7.

Singh S, Verma SK, Kumar S, Ahmad MK, Nischal A, Singh SK, et al. Evaluation of oxidative stress and antioxidant status in chronic obstructive pulmonary disease. Scand J Immunol. 2017;85(2):130-137.

Srivastava S, Singh D, Patel S, Singh MR. Role of enzymatic free radical scavengers in management of oxidative stress in autoimmune disorders. Int J Biol Macromol. 2017;101:502-517.
Sui X, Li XH, Duan MH, Jia AL, Wang Y, Liu D, et al. Investigation of the anti-glioma activity of Oviductus ranae protein hydrolysate. Biomed Pharmacother. 2016;81:176-81.

Szuroczki D, Koprivnikar J, Baker RL. Dietary antioxidants enhance immunocompetence in larval amphibians. Comp Biochem Physiol A Mol Integr Physiol. 2016;201:182-188.

Umeno A, Biju V, Yoshida Y. In vivo ROS production and use of oxidative stress-derived biomarkers to detect the onset of diseases such as Alzheimer's disease, Parkinson's disease, and diabetes. Free Radic Res. 2017;51(4):413-427.

Valko M, Leibfritz D, Moncol J, Cronin MT, Mazur M, Telser J. Free radicals and antioxidants in normal physiological functions and human disease. Int J Biochem Cell Biol. 2007;39(1):44-84.

Wang X, Xing R, Chen Z, Yu H, Li R, Li P. Effect and mechanism of mackerel (Pneumatophorus japonicus) peptides for anti-fatigue. Food Funct. 2014;5(9):2113-9.

Weber D, Davies MJ, Grune T. Determination of protein carbonyls in plasma, cell extracts, tissue homogenates, isolated proteins: Focus on sample preparation and derivatization conditions. Redox Biol. 2015;5:367-80.

Xu CJ, Ding GQ, Fu JY, Meng J, Zhang Rh, Lou XM. Immunoregulatory effects of ethyl-acetate fraction of extracts from Tetrastigma hemsleyanum Diels et. Gilg on immune functions of ICR mice. Biomed Environ Sci. 2008;21(4):325-31.

Yu ZP, Xu DD, Lu LF, Zheng XD, Chen W. Immunomodulatory effect of a formula developed from American ginseng and Chinese jujube extracts in mice. J Zhejiang Univ Sci B. 2016;17(2):147-57.

Zhang Y, Zhu K, Cui H, Liu Y, Lu YF, Pan HW, et al. Toxicological evaluation of Oviductus ranae: Acute, sub-acute and genotoxicity studies in mice and rats. J Ethnopharmacol. 2017;203:101-109.

Received for publication on $22^{\text {nd }}$ November 2017 Accepted for publication on $16^{\text {th }}$ February 2018 